\title{
Child Adoption, Posttraumatic-Stress Disorder and the Role of a Paediatrician in the Adoption Process
}

\author{
Onyiriuka AN ${ }^{1}$
}

\begin{abstract}
Child adoption represents a robust specialised child welfare service with the potential of meeting the needs and promoting the best interest of a child who have no permanent home or family to relate with. In addition, it provides succour for childless couples. Either way, there are socio-cultural challenges that need to be overcome. This paper reviews the objectives, types of adoption, circumstances in which adoption occurs, eligibility for adoption, and stress system biology/pathophysiology. Posttraumatic stress disorder in adopted children is discussed. The peculiarities and challenges of child adoption in Nigeria are highlighted. In addition, the role of a paediatrician in child adoption process is outlined. An extensive online search of the literature available in English was undertaken via electronic databases such as Nigerian Journals Online, African Journals Online, and Pubmed. Textbooks with chapters on child adoption as well as Newspapers with relevant articles on the subject were also consulted. Generally speaking, all adopted children have experienced some traumatic life event. Such an event, results in children's brains initiating adaptive stressmediating neural systems. Basically, the paediatrician guides, advises, assists and supports all parties in the adoption triad. Conclusion: The interest of each member of the adoption triad changes over time, making it necessary to design adoption process in a way that will provide protection and support for every triad member.
\end{abstract}

Key words: Child adoption, Nigeria, paediatrician, posttraumatic-stress disorder, stress system.

\section{Introduction}

C hild adoption is an important social paediatric issue but has not received sufficient attention, particularly in developing countries. Adoption is considered desirable for infants and children who have no family with which to relate. Thus, adoption provides alternative care and has the advantage of being permanent and legally secure. In this regard, it is a life-long commitment involving three parties, namely the adoptee, adoptive parents and birth parents (referred to as the adoption triad or adoption constellation). Although it is widely accepted in most developed countries, its acceptance is in its infancy in developing countries. Despite lack of accurate epidemiological data
${ }^{1}$ Alphonsus N. Onyiriuka, Professor, Department of Child Health, School of Medicine, College of Medical Sciences, University of Benin, Benin City, Nigeria.

\author{
Address for correspondence \\ Dr. Alphonsus N. Onyiriuka \\ Department of Child Health, \\ School of Medicine, \\ College of Medical Sciences, \\ University of Benin, Benin City, Nigeria \\ E-mail: alpndiony@yahoo.com
}

\section{How to cite}

Onyiriuka AN. Child Adoption, PosttraumaticStress Disorder and the Role of a Paediatrician in the Adoption Process. J Nepal Paediatr Soc 2018;38(2):110-117.

doi:http://dx.doi.org/10.3126/jnps.v38i2.20815

This work is licensed under a Creative Commons Attribution 3.0 License.

$$
\text { (c) (i) }
$$


with regard to the number of children who are being adopted in Nigeria (and other developing countries), the circumstances warranting adoption is increasing in the country. Such circumstances include the increasing number of children being orphaned due to terrorists' attacks and sectarian violence in various parts of Nigeria, natural disasters, HIVIAIDS, and road traffic accidents. Other circumstances that may necessitate child adoption are divorce, remarriage, infertility and family economic crisis. Apart from orphans, vulnerable children may require adoption. Recent estimates indicate that in Nigeria, over 12 million of Nigeria's 69 million children are either orphaned or vulnerable ${ }^{1}$. This alarming proportion of orphaned or vulnerable children is attributable mainly to increase in insurgency and sectarian violence in parts of Nigeria as well as HIV/ AIDS scourge. In the same report, almost half of the orphaned or vulnerable children are undernourished, three-quarter have no access to health care services and more than $70 \%$ have never attended school ${ }^{1}$. Over the years, Nigerian government and development partners have made some efforts to assist orphans and vulnerable children but these efforts have not yielded the desired results. One of the reasons for the poor impact of these efforts is the influence of sociodemographic factors on access and receipt of support services provided to these orphaned and vulnerable children ${ }^{2}$. Another reason is the continuing presence in our society of the circumstances that either orphaned or made the children vulnerable.

i. Definition: Adoption is a social, emotional and legal process that provides a new family for a child when the birth family is unable or unwilling to parent ${ }^{3}$. Legally, it is defined as an irrevocable transfer of rights and responsibilities concerning a child from biological or birth parents to adoptive parents ${ }^{4}$.

ii. Objectives: To provide home/family for the homeless/abandoned child and succour for infertile couple. To provide relieve to parents who are unable to care for their child. It acts as an instrument through which the 1989 United Nations Convection on the Rights of the Child can be ensured e.g., Rights to life, survival, name, development, education, protection from physical harm and neglect ${ }^{5}$. Adoption may provide to the adopted child access to good education and prevents the child being placed in an institution with the attendant risks.

iii. Circumstances that necessitate adoption by couples in Nigeria: Infertility, desire to replace a dead child, to acquire a companion for an only child, to make an illegitimate child legitimate, to perpetuate their family name, to stabilize marriage and to complete the missing gender of their offspring ${ }^{6-8}$. Adoption is most suitable for children who are in irreversible situation of abandonment.

iv. Types of adoption: Open or close adoption. In open adoption, the birth family and the adoptive family have direct contact with each other. Whereas, in close adoption, the birth family has no knowledge or contact with the adoptive family. In Nigeria, close adoption is more popular than open adoption. This is to prevent the birth parents from coming to claim the child later in life. Child adoption in Nigeria may be effected via statutory law or customary law $^{4}$. However, the rules regulating such adoption vary from one State to another in Nigeria. Child adoption can occur in variety of ways: (i) domestic adoption (adoption of a child who resides in the vicinity or country) (ii) public adoption (adoption from foster care or orphanage homes), (iii) intercountry adoption (adoptee and adoptive family are from different countries), and (iv) step-parent or kinship adoption (mutually agreed placement of a child in a home of a relative usually without the services of public agencies. It is informal but legal and it is common in eastern Nigeria), (v) private adoption (adoption arranged through an individual such as a doctor, a clergy, or an attorney).

v. Eligibility for adoption: Generally speaking, a child is eligible for adoption if he/she is acceptable to the adoptive parents, has the capacity to give and receive love, and has the potential to benefit from family life ${ }^{9}$. In Nigeria, the adoptee must be less than 18 years old, single and has never been married before $^{4}$. None of the adoptive parents must be less than 25 years old and the difference between the age of the adoptee and adoptive parents must be a least 21 years but not more than 40 years ${ }^{4}$.

vi. Principles that guide child adoption: According to Sibert ${ }^{10}$, three questions need to be answered and these represent the principles guiding adoption of a child: (1) Is the adoption in this child's best interest?

(2) Is adoption appropriate for these applicants?

(3) Are these particular applicants suitable for this particular child?

\section{Peculiarities and challenges of child adoption in Nigeria}

In Nigeria, the practice of child adoption is growing with improvement in public awareness and acceptance but still at suboptimal level. Apart from acquired immunodeficiency syndrome (AIDS), terrorist's attacks in various parts of Nigeria and natural disasters have orphaned many children, escalating the need for child adoption in the country. Another factor potentially 
encouraging adoption is the rising rate of infertility in Nigeria ${ }^{11,12}$. Adoption has become one sure way of bringing succour to childless couples. Extreme poverty leads to child abandonment, resulting in the large number of street beggars found in Nigeria. This phenomenon represents a signal for more attention to be paid to child adoption by community mobilization/enlightenment and enactment of laws to support adoption. In this regard, making the legal process of adoption less cumbersome might be helpful. Step-parent adoption is common in Nigeria because of separation, divorce and remarriage. There is paucity of epidemiological data concerning the prevalence of child adoption in Nigeria. Over a period of 11 years, data from the National Women's Commission in Enugu revealed an adoption rate of 5.5 per year ${ }^{8}$, representing a gross underestimation because the practice of adoption is shrouded in secrecy. When compared with USA, a National Survey of Adopted Children in 2007 revealed that $2 \%$ of total population of USA children were adopted, representing 1.8million children. Of this number, private domestic adoption accounted for $38 \%^{13}$.

In Nigeria, child adoption cases are handled by the civil court and it is regulated by the National Child's Right Laws of 2003 enacted by the National Assembly with commencement date of $31^{\text {st }}$ July, 2003. This Act seeks to regulate the welfare of children including adoption practices ${ }^{14}$. This Act supersedes any other law on the same subject, particularly in the Federal Capital Territory.

The incidence of illegal and unofficial child adoption practices is rising in Nigeria. Majority of child adoption cases in Nigeria are conducted privately or secretly, making prevalence rate unreliable in Nigeria. The reason is to prevent the birth parents coming to claim the child in future as well as to minimize social stigma. This illegal unofficial child adoption practice is fuelled by the emergence of "Baby Factories," in southern Nigeria, both in the east and west 15,16,17. A 'baby factory' is a phrase coined by the media and refers to a location where unmarried pregnant teenagers are quarantined until delivery of their babies. Following such delivery, these teenage mothers are paid off to give up their babies for sale. The proprietor(s) of such facility then sells the babies to prospective adopters ${ }^{6}$. In 2014, Balogun in western Nigeria ${ }^{18}$ and Kupoluyi in eastern Nigeria ${ }^{19}$, separately reported in the newspapers that babies from such 'factories' are sold for at least three hundred thousand Naira $(\mathrm{N} 300,000)$ and five hundred thousand Naira (N500,000), respectively; (1US Dollar equivalent to 360 Naira). Those who patronize these baby factories consist of a mixture of individuals-genuine prospective adoptive parents who need the babies for descent reasons and fake ones who require babies for ritual purposes and/or child trafficking ${ }^{6,8}$. Factors that have been identified that contribute to the growth of this baby factory phenomenon in contemporary Nigeria include abject poverty, rising prevalence of infertility, social shame for out of wedlock pregnancies, decay in moral and social values, poor regulation and monitoring of operation of orphanage homes ${ }^{20}$. The difficulties associated with the legal process of child adoption in Nigeria may be contributory. Inadequate law enforcement contributes to the boom in the illegal trade of selling and buying of babies of illiterate-povertystricken teenage girls. With regard to prosecuting offenders, the variations in adoption laws in operation across the states of Nigeria make the duties of the law enforcement agents difficult. Therefore, it is important that all states in Nigeria domesticate and implement the National Child's Right Act of $2003^{14}$. This will help in reducing the activities of illegal adoption agencies and provide legal backing for adoptive parents and adoptees against socio-cultural discrimination.

Some women fake pregnancies, purchase babies from baby factory operators and parade themselves as the biological mothers of such babies. The aim of this deceitful practice is to hoodwink neighbours into acknowledging that she is capable of achieving pregnancy, thereby liberating herself from the innuendoes associated with infertility in Nigeria. With regard to the child, she attempts to secure cultural acceptability for the newborn baby and remove the subsequent stigma associated with an adopted child in later life ${ }^{6}$. This type of deviant behaviour associated with child adoption in Nigeria represents an alternative but unacceptable and illegal means of achieving a socially approved goal of procreation following marriage. These illegal child adoptions do not allow for monitoring of adoptive parents to ensure the safety and well-being of the adoptees.

What is the position of religion with regard to child adoption? Both in the Old and New Testaments of the Bible, there are instances of child adoption. For example, in the Old Testament, the son of Jochebed (a Hebrew woman) was adopted by Pharoah's daughter into the royal family and named him Moses (Exodus 1:15-22; Exodus 2:1-10). In the New Testament, Jesus was conceived through the Holy Spirit (Matthew 1:18) and Joseph (His mother's husband) adopted him. Joseph took Jesus as his own child and along with Mary they brought him up and he changed the course of history. The Christian religion discourages discrimination against an adopted child. Therefore, it is expected that an adopted child should enjoy the same rights and privileges as the biological child in the family 
setting ${ }^{21}$. Alternatively, Christianity encourages trusting and waiting on God for a child. In this context, some Christians may perceive adopting a child as a sign of lack of faith in God's ability to bless them with their own child. Islamic law recognizes guardianship and foster parenting ${ }^{2}$. In this regard, the concept of 'Kafala' (a term derived from a word that means "to feed") requires that a child who cannot be cared for by the biological or birth parents may be taken by another family to live with them permanently but the child is not entitled to adopt the family name or inherit from the family ${ }^{22}$. In Islamic jurisprudence, it is emphasized to the adoptive parents that they are not taking the place of the birth parents. In that legal system, the adoptive parents are viewed as trustees and caretakers of someone else's child $^{23}$. Therefore, in the real sense, Islam prohibits child adoption because it is perceived as unjust to assign paternity of a child to another person other than the child's birth parents. According to a recent essay published online by "Law Teacher," it stated that under the Hindu law, the adoption of a child implies that that child is totally uprooted from the birth family and transplanted into the adoptive family. However, to actualize this, stringent conditions have to be met. For example, adoption of a child of the same gender is not allowed where an adoptive father or mother already have a child living at that time. In addition, adoptive parents must not have a Hindu son, a grandson or a great-grand son alive. Likewise, a person who has a Hindu daughter or son's daughter cannot adopt a daughter. In the same essay, it was stated that efforts to reduce gender bias between fathers and mothers regarding the adoption process is gradually taking place ${ }^{24}$. Under the Hindu Adoption and Maintenance Act (HAMA), there are plans to make registration of adoption mandatory with the country's apex adoption body. Such a move is part of effort to check trafficking.

The reports of various studies in Nigeria revealed that barriers toward child adoption include (i) social stigmatization, (ii) difficulties in the legal process of adoption, (iii) fear of disloyalty by the child, (iv) future claim by the biological parents, (v) lack of genetic linkage with the child $6,7,8,11,12,15$. The resultant effect of these barriers to child adoption is that many motherless babies and abandoned children who are eligible for adoption are left in the orphanage homes with relatively poor care and uncertain future.

In Nigeria, separate studies from Kano, Ibadan and Enugu indicate that foster parenting is more prevalent than child adoption ${ }^{25,26,27}$. A study in Enugu, south eastern Nigeria revealed that majority of the respondents prefer to adopt a child in the neonatal age group with slight preference for the male gender ${ }^{28}$.
Adoption in the neonatal period is believed to lead to better bonding and attachment between the adoptee and adoptive parents. In contrast, a study in Zaria, northern Nigeria indicates that more females than males are adopted ${ }^{7}$. The reasons for gender selection in child adoption include continuity of family lineage as well as allowing for inheritance in the case male adoptees. Wrong perception by adoptive parents that controlling females is less tasking may explain preference for the female child ${ }^{7}$. In addition, the prospect of giving females out in marriage with the attendant benefits may be another reason for preferring females over males in adoption. Avimide et $\mathrm{al}^{7}$ reported that the majority of the respondents prefer to adopt children aged six months and below. Reports of various studies from eastern Nigeria revealed that infertility was the most single important reason for child adoption $n^{4,21}$ and closely followed by gender balancing among couples who have their own biologic children ${ }^{6}$. Willingness to consider adoption was higher among Nigerian Christians than Moslems ${ }^{7}$. In the same study, willingness to consider adoption was higher among the Yorubas and the Hausas compared to other tribes in Nigeria ${ }^{7}$. In an executive summary of literature on child adoption, Fagan stated that adoption in the first 12 months of the child's life produces the best outcomes, but all children benefit regardless of their age at adoption ${ }^{29}$. Other authorities have also recognized the overall benefit of adoption on various aspects of the adoptee's life ${ }^{30}$.

\section{Stress system biology and pathophysiology}

Generally speaking, all adopted children have experienced some traumatic life event. Such an event, results in the child's brain initiating adaptive stress-mediating neural systems. The stress system, including hypothalamic-pituitary-adrenal (HPA) axis and the locus caereleus/norepinephrine-sympathetic nervous system (LC/NE/SNS), and the associated central and peripheral nervous system mechanisms provide the adaptive emotional, behavioural, cognitive and physiological changes necessary for survival ${ }^{31,32}$. A childhood traumatic event can potentially alter central nervous system development because the brain is not structurally complete at birth. For example, myelination, proliferation of synaptic connections, and development of glial and circulatory support systems all continue long after birth ${ }^{33}$. Early severe stress results in elevated levels of corticotrophin releasing hormone $(\mathrm{CRH})$ and glucocorticoids affecting specific vulnerable areas of the brain $^{34}$. Proper structural development is guided by environmental cues as the infant's brain adapts to what it sees, hears or feels, particularly during the 'critical period' for effective development of many brain systems ${ }^{33}$. Effective stimulation requires interaction with 
other people. Other people must be present, attentive enough, and consistent/predictable enough to teach the lessons the developing brain needs ${ }^{33}$. Gene expression determines neuroendocrine structure and it is strongly influenced by experience ${ }^{33}$. Research in genetics has identified a variety of gene alleles that appear to protect against or predispose to long-term sequelae of traumatic stress by varying the sensitivity of stress-hormone receptors in the limbic system ${ }^{35,36}$. An increasing body of evidence points to the ability of early life experience to trigger epigenetic modifications, effectively altering brain structure by changing gene transcription ${ }^{36,37}$. The body systems are mutually interactive. Social interaction (or the lack thereof) may affect neuroendocrine development, which can alter observed behaviours. In turn, behaviour produces social feedback, which stimulates neuroendocrine response (a physiologic response) and, if severe, may cause modification in brain structures (anatomic response) ${ }^{36,38}$. The genes and epigenetic modifications to their transcription ultimately determine the brain's structure which govern behaviour. This interactive cascade of responses among social/ behavioural, neuroendocrine, and genetic/epigenetic systems has recently been referred to as "eco-biodevelopmental model" 39 .

\section{Posttraumatic stress disorder in adopted children}

Posttraumatic Stress Disorder (PTSD) describes the clustering of symptoms that develop after exposure to a traumatic life event that involve actual death, injury or a threat to the physical integrity of the individual or others and that evoked intense fear, helplessness, or horror ${ }^{32}$. PTSD is classified as an anxiety disorder based on DSM-IV ${ }^{39}$. Paediatric PTSD is an underrecognized public health issue and parents, teachers and even mental health professionals significantly under estimate both the intensity and the duration of the stress reactions ${ }^{40,41}$. It is estimated that $20-30 \%$ of children exposed to traumatic stress develop PTSD ${ }^{42,43}$. The results of one meta-analysis involving 34 samples and 2,697 children who had experienced traumatic life events revealed that $36 \%$ of the children met the criteria for diagnosis of PTSD ${ }^{44}$. In the same report, the agegroup-specific prevalence rates for PTSD were 39\% in $<7$ years old, $33 \%$ in $6-12$ years old and $27 \%$ in $>$ 12 years old children ${ }^{44}$. Symptoms of PTSD can be considered in three clusters, namely (i) re-experiencing of the traumatic event with disturbing memories or flashbacks e.g., nightmares and fear of re-experiencing traumatic event; (ii) avoidance behaviour e.g., avoiding thoughts, feelings, conversations regarding the event, inability to recall important aspects of the event, feeling of detachment or estrangement from others or frank withdrawal; and (iii) hyperarousal e.g., hyper-vigilance, exaggerated startle response, difficulty falling or staying asleep, difficulty concentrating, irritability or outburst of anger ${ }^{40,43}$. According to the American Psychiatric Association, the criteria for the diagnosis of PTSD are the presence of one symptom of re-experiencing of the traumatic event, three symptoms of avoidance and two symptoms of hyperarousal ${ }^{45}$. In addition, the duration of the symptoms must be at least one month and be severe enough to interfere with relationships or work ${ }^{42}$. In children below six years, symptoms of PTSD may include (a) wetting bed after having learnt to use the toilet; (b) forgetting how to or being unable to talk; (c) acting out the scary event during playtime; and (d) being unusually clingy with a parent or other adult ${ }^{34}$. PTSD results from the interplay between the traumatic experience and the psychological nature of the recipients, accounting for variations in phenotypic manifestations in victims. According to The National Children's Traumatic Stress Network (NCTSN) definition of traumatic stress, it encompasses the physical and emotional responses of a child to events that threaten the life or physical integrity of the child or of someone critically important to the child (such as a parent or sibling $)^{33}$. Depending on the associated physiological arousal the child may show maladaptation but this varies from child to child. This variability depends on the child's previous trauma history, available social support and genetic predisposition ${ }^{33}$. It is important to recognize that adopted children represent individuals with special health care needs. Well-established therapies for PTSD in children and adolescents include ${ }^{46}$ : (i) individual cognitive behavioural therapy (CBT); (ii) individual CBT with parent involved; and (iii) group CBT.

Although this paper dwelt largely on the mental health impact of adoption on the adopted child (adoptee), it is important to note that adoption process affects the adoption triad, namely (i) the adoptee, (ii) the adoptive parents, and (iii) the birth parents. In this regard, the adoptee has lost a set of parents and a sense of roots, history, and identity. The birth parents have lost a child with an attendant sense of personal moral worth and integrity. The adoptive parents have lost their sense of reproductive competence and the child of their fantasies ${ }^{9}$.

\section{The role of a paediatrician in child adoption}

Paediatricians can be most helpful by assisting the adoption triad to recognize and successfully adapt to their new and generally unanticipated roles and circumstances.

1. Evaluation in preparation for child adoption. 
a. Medical records review: Help the prospective adoptive parents evaluate the health and developmental history of the child. Obtain background information from birth family to assess actual or potential problems or risks. Thus, the paediatrician screens for and identifies trauma in the life of the child. Investigate for genetic diseases, alcohol or drug abuse during pregnancy, health of parents, and difficulties associated with the perinatal period.

b. Physical examination consists of identification data, anthropometry, developmental status, examination of body systems including careful documentation.

c. Standard investigations which are expected to be performed include: haematocrit, urinalysis, manteaux test, Chest X-ray, stool examination for parasites, test for VDRL, HIV, Hepatitis B. Depending on the findings from history and physical examination, other special tests include thyroid function test, haemoglobin genotype, karyotype ${ }^{47}$.

d. Information sharing:

Frank interpretation of available information should be fully shared with prospective adoptive parents. The adoptive parents must be told clearly and honestly of any special health needs detected now or anticipated in the future.

e. Note that it is not the paediatrician's role to judge the advisability of a proposed adoption.

1. Post-adoption Care

a. After the child has settled in his/her new home, the paediatrician should encourage the adoptive parents to seek a comprehensive assessment of the child's health and development.

b. The paediatrician should be alert with regard to some clinical conditions. Majority of children adopted after age one month and those who were not abandoned immediately after delivery are highly vulnerable to sepsis, malnutrition, frequent attacks of acute respiratory infections, diarrhoeal diseases, and skin infections ${ }^{47}$.

c. The paediatrician should ensure the child is fully immunized for age.

2. Follow-up and post-adoption counselling

a. Encouraging, insisting and helping the adoptive parents to tell the child about his/her adoption is a vital follow-up action. If the adoptee learns about it from an outside source, it brings severe trauma of betrayal or breach of trust which may ruin the entire relationship and the fundamental objective of the adoption process. The discussion can begin with children between the age of 5 and 7 years ${ }^{9}$.

b. If and when the adoptee adolescent desires to search for her/his biological root, the paediatrician should encourage the adoptive parents to help with the search.

c. The paediatrician empowers the families to respond to the children in ways that acknowledge their past trauma/chronic stress as well as help the children to learn new, adaptive reactions to stress.

d. The paediatrician can play an important role in helping parents understand adoption-related health issues and determine what benchmarks are considered as routine development.

e. The paediatrician can help make appropriate social service and mental health referrals.

f. The paediatrician should work closely with the child's school to address behavioural challenges to learning and help coordinate care among specialists in other disciplines.

In conclusion, despite the socio-cultural challenges faced by the all the parties in the adoption triad, it is beneficial to all including the society. Importantly, the paediatrician's role is to assist the adoptee, adoptive parents and birth parents to recognize and successfully adapt to their new roles and circumstances.

Recommendations: In developing countries, it is advocated that:

i. Cultures that hinder child adoption should be reformed.

ii. Existing laws guiding child adoption should be enforced and defaulters punished.

iii. In countries were the laws that guide child adoption differ from State to State, it should be harmonized.

iv. More motherless baby homes should be established, both in urban and in rural areas, to cater for abandoned and motherless babies.

v. Opinion leaders in our various religions and communities should create more awareness concerning the evils of 'baby factories'. 
vi. Adopted children should not be denied their rights or stigmatized because of their birth circumstances.

vii. Government should monitor any adopted child to ensure that the adoptive parents are taking good care of the child.

viii. To prevent the potential social catastrophe that the adoptive parents will encounter should the adopted child decide in future to return to his/her natural family, adoption should be reserved for only children whose parents are not known.

ix. Step-parents or kinship adoption is preferable in developing countries. This will enable the child to maintain contact with his/her natural family, even if trivial.

\section{References}

1. Save the Children (2016). North East Nigeria. Children's Lives and Future at Risk. Briefing Paper, 2016.

2. Chima V. Socio-demographic determinants of health support services among orphans and vulnerable children in Nigeria. J Public Health Epidemiol 2018;10(5):165-70. DOI: 10.897/JPHE2017.0981.

3. Simms MD, Freundlich M. Adoption. In: Kliegman RM, Behrman RE, Jenson HB, Stanton BF (editors) Nelson Textbook of Pediatrics $18^{\text {th }}$ ed, Philadelphia, Saunder Elsevier, 2007:163-64.

4. Ibraheem TO. Adoption Practice in Nigeria - an overview. J Law Policy Globalisation 2013;19:7-13

5. United Nations General Assembly. Convection on the Rights of a Child. Available at: http://www.un.org/ documents/ga/res/44/a44.025.htm. Accessed June 16, 2018.

6. Agbo MA. Socio-cultural challenges of child adoption in eastern Nigeria in West Africa. Humanities Social Sci Rev 2014;2(1):86-93.

7. Avidime $\mathrm{S}$, Ameh N, Adesiyun AG, Ozed-Williams C, Isaac $N$, Aliyu $Y$, Suilyman $K$, Idris $H$, Ojabo A. Knowledge and attitude towards child adoption among women in Zaria, northern Nigeria. Nig Med $J$ 2013;54(4):261-63. DOI: 10.4103/0300-165211965.

8. Aniebue PN, Aniebue UU. Adoption practices in Enugu, Nigeria. Niger J Clin Pract 2008;11(1):5-8.

9. Schor EL. Adoption and foster care. In: Ambulatory Pediatrics IV, Green M, Haggerty RJ (eds). W.B. Saunders Company, Philadelphia, 1990:55-8.

10. Sibert JO. APocket Handbook of Social and Community Paediatrics. Edward Arnold, London, 1992:61-5.

11. Adetoro OO, Ebomoyi EW. The prevalence of infertility in a rural Nigerian community. Afr J Med Sci 1991;20(1):23-7.

12. Adewunmi AA, Etti EA, Tayo AO, Rabiu KF, Akindele RA, Ottun TA, Akinlusi FM. Factors associated with acceptability of child adoption as a management option for infertility among women in a developing country. Int $J$ Women Health 2012;4:365-72.

13. Vandivere S, Malm K, Radel L. Adoption USA: A Chartbook Based on the 2007 National Survey of Adoptive Parents Washington, DC. US Department of Health and Human Services, Office of Assistant Secretary for Planning and Evaluation 2009. Available at: http://aspe.hhs.gov/hsp/09/NSAP/chartbook/ Accessed January 20,2012.

14. Federal Ministry of Women Affairs. Child Right Act. Simplified version, 2005:1-16.

15. Omeire CO, Iheriohanma EBJ, Osita-Njoku A, Omeire EU. The challenges of child adoption and the emergence of baby factory in south eastern, Nigeria. Int J Educ Res 2015;3(8):63-74.

16. Alfred C, Francis AA, Andeshi CA. Dialectics of the incubation of 'Baby Factories' in Nigeria. Int J Peace Conflict Studies 2014;2:82-90.

17. Chioma PE, Ayaosi OF, Adekoya HO. Assessing media coverage of baby factory discovery in Ifo Local Government Area, Ogun State, Nigeria. Int J Humanities Social Sci Educ 2015;2(9):187-93.

18. Balogun S. Police in Ogun uncovers baby-making factory, den of ritualists. In: This Day Live, April 4, 2014. Available at: http://www.thisdaylive.com/article/ police-in-ogun-uncovers-baby-making-factory-den-ofritualists/175425/

19. Kupoluyi A. Ending baby factory menace. The Nation Newspaper, April 15, 2014, page 13.

20. Onuoha FC. New wares of trade: understanding evolving baby factory and trafficking in Nigeria. Available at: http://www.x005.freedomonuoha/ newwaresoftrade:Understanding Evolving Baby Factory and TraffickinginNigeria.pdf. Accessed February 23, 2015.

21. Nwaoga CT. Socio-religious implications of child adoption in Igboland south eastern, Nigeria. Mediterranean J Social Sci 2013;4(13):705-10. DOI: 10.5901/mjss.2013.v4n13p705.

22. Kafala. Adopting a child in Islam. Available at: http:// www.islam.about.com/cs/parenting/a/adoption.htm. Accessed July 9,2018

23. Anonymous. Adopting a child in Islam. Islamic rulings about foster parenting and adoption. Available at: http://islam.about.com/cs/parenting/a/adoption.htm. Accessed June 28, 2018.

24. Law Teacher Net. December,2018. Adoption in Hindu law and Muslim law. Available at: http://www. lawteacher.net/free-law-essays/familylaw/adoptionhindulaw-muslimlaw essay-php?vref-1. Accessed December 13,2018. 
25. Abubakar S, Lawan UM, Yasir JN. Knowledge and attitudes toward child adoption and fostering among infertile women in northern Nigeria. Sahel Med J 2013;16(1):19-23.

26. Oladukun A, Arulogun O, Oladukun R, MorhasonBello IO, Bamgboye EA, Adewole IF, Ojengbede OA. Acceptability of child adoption as a management option for infertility in Nigeria: Evidence from focus group discussions. Afr J Reprod Health 2009;13(1):7991.

27. Ezugwu FO, Obi SN, Onah HE. The knowledge, attitude and practice of child adoption among infertile Nigerian women. J Obstet Gynaecol 2002;22(2):21116.

28. Eke CB, Obu HA, Chinawa JM, Adimora GN, Obi IE. Perception of child adoption among parents/caregivers of children attending pediatric outpatients' clinics in Enugu, South East, Nigeria. Niger J Clin Pract 2014;17(2):188-95

29. Fagan PF. Adoption works well: A synthesis of the literature. Research Synthesis 2010:1-27.

30. Child Welfare Information Gateway. Impact of adoption on adopted persons (2013). Available at: http:// www.childwelfare.gov/pubs/impactoadoptadas.cfm Accessed June 27, 2018.

31. Perry BD, Pollard R. Homeostasis, stress, trauma and adaptation: a neurodevelopmental view of childhood trauma. Clin Adolesc Psychiatr Clin North Am 1998;7:33-51.

32. Pervanidou P. Biology of posttraumatic stress disorder in childhood and adolescence. J Neuroendocrinol 2008;20:632-38. DOI:101111/j1365-28262008.01701.x

33. Forkey H, Garner A, Nalven L, Schilling S, Stirling J. Helping foster and adoptive families cope with trauma. Available at: http://www.aap.org/traumaguide Accessed June 27, 2018.

34. Teicher MH, Andersen SL, Polcari AA. Anderson CM, Navalta CP. Developmental neurobiology of childhood stress trauma. Psychiatr Clin North Am 2002;25:397426.

35. Binder EB. The role of FKBP5, a co-chaperone of glucocorticoid receptor in the pathogenesis and therapy of affective and anxiety disorders. Psychoneuroendocrinology 2009;34(Suppl 1):S186-S195

36. McGowan PO, Sasaki A, D'Alessio AC, et al. Epigenetic regulation of the glucocorticoid receptor in human brain associates with child abuse. Nat Neurosci 2009;12(3):342-48.
37. Weinstock M. Sex-dependent changes induced by prenatal stress in cortical and hippocampal morphology and behaviour in rats: an update. Stress 2011;14(6):604-13.

38. Mehta MA, Golembo NI, Nosarti C, et al. Amygadala, hippocampal and corpus callosum size following severe early institutional deprivation: The English and Romanian Adoptees Pilot Study. J Child Psychol Psychiatry 2009;50(8):943-51.

39. Shonkoff JP, Garner AS, American Academy of Psychiatry Committee on Early Childhood, Adoption and Dependent Care; Section on Developmental and Behavioural Pediatrics. The life-long effects of early childhood adversity and toxic stress. Pediatrics 2012;129(1):e232-e246.

40. Perry BD, Azad I. Posttraumatic stress disorders in children. Curr Opinion Pediatr 1999;11(4):301-316. DOI: 10.1097/000084180-199080000-00008.

41. Cohen JA. American Academy of Child and Adolescent Psychiatry Practice Parameter for Assessment and Treatment of Posttraumatic Stress Disorder in Children and Adolescents. J Am Child Adolesc Psychiatry 1998;37(Suppl 10):245-65.

42. Hoksbergen RAC, ter Laak J, van Dijkum C, Rijk S, Rijk K, Stoutjesdijk F. Posttraumatic stress disorder in adopted children from Romania. Am J Orthopsychiatry 2003;73(3):255-65. DOI:101037/0002-9432:73.3.255.

43. Damian SI, Knieling A, loan BG. Posttraumatic stress disorder in children: Overview and case study. Rom J Legal Med 2011;19:135-40. DOI:10.4323/ RJLM.2011.135

44. Fletcher KE. Childhood posttraumatic stress disorder. In: Mash EJ, Berkley R eds. Child Psychopathology 1996:242-46.

45. American Psychiatric Association. Diagnostic and Statistical Manual of Mental Disorders. Revised $4^{\text {th }}$ edition, Washington DC, 2000.

46. Dorsey S, McLanghlin KA, Kerns SEU, Harrison JP, Lambert HK, Briggs EC, Cox JR, Amaya-Jackson L. Evidence based update for psychosocial treatments for children and adolescents exposed to traumatic events. J Clin Child Adolesc Psychol. Available at: http://dx DOI: org/10.1080/15374416.2016.1220309.

47. Potdar RD. Adoption and care of orphans. In: Parthasarathy A (ed). IAP Textbook of Pediatrics $4^{\text {th }}$ edition. Jaypee Brothers Medical Publishers, New Delhi 2009:226-28. 